\title{
Mechanisms of habitat segregation between corallimorpharians: photosynthetic parameters and Symbiodinium types
}

\author{
Baraka Kuguru $^{1,2, *}$, Nanette E. Chadwick ${ }^{3}$, Yair Achituv ${ }^{1}$, Keren Zandbank ${ }^{2}$, \\ Dan Tchernov ${ }^{2,4}$ \\ ${ }^{1}$ The Mina and Everard Goodman Faculty of Life Sciences, Bar-Ilan University, Ramat-Gan 52900, Israel \\ ${ }^{2}$ The Interuniversity Institute for Marine Science, PO Box 469, Eilat 88103, Israel \\ ${ }^{3}$ Department of Biological Sciences, Auburn University, Auburn, Alabama 36849, USA \\ ${ }^{4}$ Department of Evolution, Systematics and Ecology, Hebrew University, Givat Ram, Jerusalem 91904, Israel
}

\begin{abstract}
Corallimorpharians are evolutionarily important relatives to reef-building corals, yet little is known about their ecophysiology. We demonstrate that physiological mechanisms determine, in part, the light-dependent distributional patterns of 2 corallimorpharians, Rhodactis rhodostoma and Discosoma unguja, on coral reefs in the northern Red Sea. Field measurements of the physiological parameters related to photosynthetic activity revealed that zooxanthellae abundance, chlorophyll a concentration, maximum quantum yield $\left(F_{\mathrm{v}} / F_{\mathrm{m}}\right)$, and excitation pressure of Photosytem II $\left(\mathrm{Q}_{\mathrm{m}}\right)$ varied equally for both species among 3 depths. In contrast, laboratory measurements in 3 experimental light treatments - low light (LL), medium light (ML) and high light (HL) - revealed that D. unguja was more sensitive to HL than $R$. rhodostoma. Genetic characterization of their endosymbiotic algae using a PCR for the internal transcribed spacer region (ITS2) of nuclear ribosomal DNA showed that both $R$. rhodostoma and D. unguja contain Symbiodinium ITS2-type C1 symbionts in shallow areas, but that the algal assemblage were either Type C1 or Type D1a in both species in deeper areas. In reciprocal depth, light, and temperature manipulation experiments, bleached $R$. rhodostoma never shuffled Symbiodinium ITS2 types, however, some $R$. rhodostoma in the control treatment did. In contrast, some individuals of $D$. unguja shuffled Symbiodinium ITS2 types both in field-reciprocal experiments and laboratory-control treatments. Both species contained UV radiation absorbing compounds over a wide-depth range. We concluded that the photoacclimation mechanisms of $R$. rhodostoma and $D$. unguja were influenced by both host- and symbiont-mediated factors. We hypothesize that a low abundance of $D$. unguja in shallow water was due to decreased tolerance to the high irradiance found in host factors.
\end{abstract}

KEY WORDS: Photoacclimation mechanisms - Corallimorpharians · Photosynthetic parameters · Zooxanthellae

\section{INTRODUCTION}

Coral reefs are threatened by a steady rise in atmospheric $\mathrm{CO}_{2}$ that has lead to high sea-surface temperatures (SST) (Hoegh-Guldberg 1999) and lower pH levels. The past 3 decades have been marked by massive coral mortality caused by elevated SST-induced loss of photosynthetic algal symbionts (bleaching events, reviewed in van Oppen \& Gates 2006). Moreover, several reports indicate that a steady decrease in oceanic pH may cause corals to lose their skeletons (Fine \& Tchernov 2007) and cause reefs as we know them today to disappear.

Recent studies by Medina et al. (2006) showed that corallimorpharians diverged from scleractinian corals during the early Cretaceous, a period dominated by a 
combination of high atmospheric $\mathrm{CO}_{2}$ concentrations and elevated temperatures (Berner 1992). During the early Cretaceous, multiple calcifying scleractinians became extinct (Buddemeier 1996), but many survived and radiated into considerable diversity (ChadwickFurman 1996, Stanley 2003). The surviving corallimorpharians may have lost their ability to calcify, but they maintained primary life functions, perhaps creating a means to increase fitness in a relatively acidic sea with low Mg/Ca ratios (Stanley 2003, Medina et al. 2006). Loss of skeleton in corallimorpharians may have been compensated for by enhanced physiological capabilities as a means of coping with environmental changes. Understanding more about the physiological properties of corallimorpharians offers an opportunity to uncover a latent chapter in the evolution of corals and their ability to survive immense climatic changes. While the effects of light and temperature stress on reef-building corals have been extensively studied, corallimorpharians have been almost completely overlooked in this context, despite their key evolutionary role.

The corallimorpharians Rhodactis rhodostoma and Discosoma unguja are nonreef-building invertebrates that commonly occupy shallow coral reefs in the IndoPacific region and may successfully dominate some reef areas following bleaching and other disturbances that kill stony corals (Chadwick-Furman \& Spiegel 2000, Kuguru et al. 2004). Polyps of $R$. rhodostoma and $D$. unguja occupy contrasting habitats on coral reefs in the northern Red Sea. Individuals of $R$. rhodostoma form large aggregations on intertidal reef flats (Kuguru et al. 2007), while those of D. unguja occupy holes and crevices on the reef slope (B. Kuguru pers. obs.). Differences in their physiological acclimation to photosynthetically active radiation, UV radiation and temperature may partly explain their distributional patterns, but they are not well understood. Like many marine invertebrates, some corallimorpharians are hosts to endosymbiotic dinoflagellate algae, commonly known as zooxanthellae (den-Hartog 1980, LaJeunesse 2002, Kuguru et al. 2007). Zooxanthellae predominantly belong to the genus Symbiodinium and play a vital role in host nourishment via translocation of photosynthates (Muscatine et al. 1981). Ample evidence indicates that different host-symbiont associations have led to the development of mechanisms that enable them to offset the effects of a variety of environmental stresses and to occupy different niches within the reef (Goulet \& Coffroth 2003, Tchernov et al 2004, Sampayo et al. 2007). Symbiont-based mechanisms include changes in pigment concentrations and ratios, dinoflagellate densities, quantum yields of photosynthesis (Stambler \& Dubinsky 2004), and changes in the abundance of different Symbiodinium types (Baker
2003, Little et al. 2004). These symbiont traits are complemented by physiological and morphological changes in the host, such as alteration of host tissue thickness (Hoegh-Guldberg 1999), protein turnover (Gates \& Edmunds 1999), host protective pigments (Dove et al. 2006), and (UV absorbing substances) mycosporine-like amino acid (MAA) production in host-symbiont associations (Yakovleva \& Hidaka 2004). However, only some of these mechanisms have been observed in corallimorpharians (Kuguru et al. 2007). In our previous study (Kuguru et al. 2007), we reported that the corallimorpharian $R$. rhodostoma employs multiple mechanisms of photoacclimation, including (1) variation in both zooxanthellae abundance and chlorophyll concentration with depth; (2) dispersal of excess light energy via nonphotochemical quenching (NPQ) by the zooxanthellae at high light levels (HL); (3) host-mediated shading of zooxanthellae from HL by thickening of the endodermal layer and movement of algal cells away from the mesoglea; and (4) variation in the genetic identity of harbored zooxanthellae clades with depth.

We hypothesize that the contrasting distributional patterns of the corallimorpharians Rhodactis rhodostoma and Discosoma unguja may be partly explained by physiological differences in their host-symbiont associations. Specifically, we propose that polyps of $R$. rhodostoma are less sensitive to environmental stressors compared to $D$. unguja, that their host-symbiont associations vary with reef depth according to the physiological optimum of the holobiont, and that the different algal types within the corallimorpharians are selectively up-regulated by the host when subjected to the environmental stressors of high irradiance and temperature.

\section{MATERIALS AND METHODS}

Study sites and field surveys. The study period began in January 2005 and lasted until April 2006. Research was conducted on coral reefs adjacent to the Interuniversity Institute for Marine Science (IUI) in Eilat, Israel, in the northern Red Sea $\left(29^{\circ} 30^{\prime} \mathrm{N}, 34^{\circ} 55^{\prime} \mathrm{E}\right)$.

Experimental design: We assessed 4 major ecophysiological characteristics of 2 corallimorpharian species, related to light acclimation: (1) bathymetric distribution pattern; (2) physiological response related to photosynthesis; (3) Symbiodinium types associated with corallimorpharians at different depths, light, and temperatures; and (4) UV-absorbing substances. These parameters were selected because they reflect microhabitat preference of sessile photosynthetic invertebrate organisms in response to changes in environmental parameters such as light and temperature. 
The bathymetric study of the corallimorpharians Rhodactis rhodostoma and Discosoma unguja was conducted in order to understand how changes in light with depth affect their distribution pattern. To determine the depth distributions of these corallimorpharians, 20 quadrats $\left(1 \mathrm{~m}^{2}\right.$ each) were deployed haphazardly at each of 3 depths on the coral reef adjacent to the IUI: reef flat $(0.5 \mathrm{~m})$, shallow slope $(3 \mathrm{~m})$, and deep slope $(18 \mathrm{~m})$. The number of polyps of each species in each quadrat was counted during snorkeling or SCUBA diving.

Collection and maintenance of corallimopharian polyps: Polyps of Rhodactis rhodostoma and Discosoma unguja were collected at depths of 3 to $20 \mathrm{~m}$ and glued to PVC bases using underwater epoxy. Care was taken to ensure that the replicate polyps were collected from areas at least $10 \mathrm{~m}$ apart on the coral reef, in order to avoid individuals that originated asexually from the same parent colonies. Following a 2 wk acclimation period in outdoor aquaria (irradiance of $\sim 615 \mu \mathrm{mol}$ photons $\mathrm{m}^{-2} \mathrm{~s}^{-1}$ equivalent to that at $10 \mathrm{~m}$ depth, flow-through seawater at $120 \mathrm{l} \mathrm{h}^{-1}$ ), the polyps were either returned to the reef for in situ field experiments or transferred to the laboratory for treatment (see below, as per Kuguru et al. 2007).

Field experiments: The field experiments were performed in order to understand how the symbiotic association of 2 species of corallimorpharians and their photosymbionts (zooxanthellae) respond to changes in environmental conditions, such as light and depth, under their natural growth conditions. The hostsymbiont association with physiological plasticity exhibits a wide range of distributions and better acclimation mechanisms to environmental changes. In order to understand the difference between the physiological plasticity of Rhodactis rhodostoma and Discosoma unguja, we designed 2 separate sets of field experiments, 1 conducted on photosynthetic parameters and the other on changes in zooxanthellae types with depth in the corallimorpharians.

In the first experiment, on physiological responses to light, we measured chlorophyll a ( $\mathrm{chl}$ a) fluorescence of corallimorpharian zooxanthellae. In situ chlorophyll fluorescence signatures provide insight into the daily homeostasis and stress response of the symbiotic algae. In this experiment, 4 corallimorpharian polyps of each of the 2 species were attached via their PVC bases to underwater frames and acclimated at each of 3 depths $(5,10$, and $20 \mathrm{~m})$ for $30 \mathrm{~d}$ on the reef adjacent to the IUI. Following acclimation, we used a pulseamplitude modulated (PAM) fluorometer (Diving PAM) (Hoegh-Guldberg \& Jones 1999, Winters et al. 2003, Iglesias-Prieto et al. 2004) to measure photosynthetic parameters in each corallimorpharian polyp. PAM fluorometry-induced chl a fluorescence was measured in vivo in order to estimate the potential quantum yield of Photosystem II (PSII) during photosynthesis, a parameter that correlates with more traditional measures of photosynthetic rate such as $\mathrm{CO}_{2}$ uptake and $\mathrm{O}_{2}$ evolution (Beer et al. 1998). At $1 \mathrm{~h}$ after sunset, the PAM was used to record the nocturnal maximum quantum yield of PSII $\left(F_{\mathrm{v}} / F_{\mathrm{m}}\right)$, where $F_{\mathrm{v}}=$ variable fluorescence and $F_{\mathrm{m}}=$ maximum fluorescence for the dark-adapted sample.

This period of darkness was sufficient to maximize the frequency of open-reaction centers in PSII (Winters et al. 2003, Kuguru et al 2007). At noon, the midday effective quantum yield $\left(F_{\mathrm{m}}{ }^{\prime}-F\right) / F_{\mathrm{m}}{ }^{\prime}=\Delta F / F_{\mathrm{m}}{ }^{\prime}$ was also measured, where $F_{\mathrm{m}}{ }^{\prime}=$ maximum fluorescence and $F=$ initial fluorescence for the light-adapted sample (according to Genty et al. 1989). Based on these measurements, we calculated for each polyp the maximum midday excitation pressure on PSII, $\mathrm{Q}_{\mathrm{m}}=1-\left(\Delta F / F_{\mathrm{m}}{ }^{\prime}\right.$ at noon $) /\left(F_{\mathrm{v}} / F_{\mathrm{m}} 1 \mathrm{~h}\right.$ after darkness) (Maxwell et al. 1995). Values of $Q_{m}$ close to 0 indicate that even during periods of maximum irradiance, most of the reaction centers of PSII remained open, suggesting that photosynthetic rates are light-limited. Values close to 1.0 indicate that under maximum irradiance, most PSII reaction centers are closed, suggesting photoinhibition (Iglesias-Prieto \& Trench 1997, Iglesias-Prieto et al. 2004).

Differences in $F_{\mathrm{v}} / F_{\mathrm{m}}$ and $\mathrm{Q}_{\mathrm{m}}$ among symbionts within some corals have been shown to provide a predictive measure of how different coral species or colonies with different algal symbionts respond to natural light and thermal stress (Iglesias-Prieto et al. 2004, Warner et al. 2006). After chl a fluorescence measurements were taken, tissue samples (ca. $0.5 \mathrm{~g}$ ) from the tentacles were removed from each corallimorpharian polyp to determine zooxanthellae abundance and chl a content. The tentacles were examined because they are major photosynthetic organs in anthozoans, and have been widely used to assess variation in these photosynthetic parameters (Dunn et al. 2002, Kuguru et al. 2007). The tentacle tissue sample from each polyp was blotted on absorbent tissue paper to remove all excess water. Following this, wet mass was determined using an electronic microbalance with an error of $\pm 0.0002 \mathrm{~g}$ (wet mass of each tentacle/oral disc tissue sample = $0.10 \pm 0.02 \mathrm{~g}$, mean $\pm \mathrm{SE}$ ). Each tissue sample was then homogenized in $2 \mathrm{ml}$ of filtered seawater and the resulting slurry was centrifuged (according to Dunn et al. 2002, Kuguru et al. 2007). In the zooxanthellaecontaining aliquots, we measured (1) chl a content (overnight extraction in $90 \%$ acetone, absorbance readings at 750,664, and $630 \mathrm{~nm}$ [Jeffrey \& Humphrey 1975]); and (2) zooxanthellae abundance: cells were counted under a light microscope using a hemocytometer. Algal pigment and abundance were normal- 
ized per wet mass of tentacle tissue (Kuguru et al. 2007).

In the second field experiment, polyps were reciprocally transplanted to determine the extent to which they alter their symbiont types with depth on the coral reef. Eight polyps of each species were collected at 2 depths (5 and $20 \mathrm{~m}$ ), and each affixed to a PVC base. Then, 4 bases, each containing a polyp, were attached to a $4 \times 30 \mathrm{~cm}$ plastic plate. One of the 2 plates per species $(\mathrm{n}=4$ polyps per plate $\times 2$ plates per species $=8$ polyps total per species) contained treatment polyps that were mounted on an underwater frame at the opposite depth from that of polyp origin (5 and $20 \mathrm{~m}$ ), and allowed to acclimate for $3 \mathrm{mo}$. The second plate for each species contained control polyps and was fixed on an underwater frame to the original depth of collection. After $3 \mathrm{mo}$, the treatment polyps (1 plate per species) were moved back to their original depths (5 and $20 \mathrm{~m}$ ) and re-acclimated for an additional 6 mo. The control polyps were not moved in order to assess any variation over time in algal symbiont identity that did not relate to changes in reef depth. Tissue samples were collected from all polyps prior to transplantation, at 3 mo after placement of the treatment polyps at opposite depths, and 6 mo after returning the treatment polyps to their original depths. Zooxanthellae were isolated and total nucleic acids extracted from these samples, as described below (Coffroth et al. 1992).

Determination of $U \boldsymbol{V}$-absorbing substance (UAS) levels: A separate sampling was conducted to assess levels of UV-absorbing substances (UAS) present in the corallimopharians. UAS protect marine organisms from the biological effects of ultraviolet radiation (UVR), mostly experienced in shallow waters, where UVR is more pronounced. However, the bioaccumulation of UAS differs within and between species and decreases bathymetrically at sea. Differences in bioaccumulation of UAS can be used as a physiological indicator of the ability of an organism to adjust to changes in irradiance. In this study, we aim to understand if there is any difference in the bioaccumulation ability of UAS between Rhodactis rhodostoma and Discosoma unguja. In this experiment, a small section of coral disc tissue $(\sim 1 \mathrm{~g})$ was removed from each of 4 polyps belonging to each species at each of 2 depths (5 and $20 \mathrm{~m}$ ) on the reef. The collected tissue was homogenized in $2 \mathrm{ml}$ of filtered seawater and aliquots from the resulting slurry were used to assess either (1) total protein (according to Bradford 1976), or (2) the UVabsorbing substances (according to Hirose et al. 2006). The aliquots for UV-absorbing substance analysis were extracted overnight in a 1:4 ratio of sample slurry to $100 \%$ HPLC-grade methanol at $4^{\circ} \mathrm{C}$. After brief centrifugation $(3300 \times g$ for $5 \mathrm{~min})$, the absorption spectra of the extracts (280 to $400 \mathrm{~nm}$, at $1 \mathrm{~nm}$ intervals) were recorded using a spectrophotometer (modified from Hirose et al. 2006). UAS pigment was normalized per total protein content of the polyps. This technique provides a relative, rather than absolute, measure of UAS content and assumes that the absorption spectra are similar in shape for all sampled polyps.

Laboratory experiments. Two types of laboratory experiments, which were similar to the field experiments, were also performed: (1) on effects of irradiance level on photosynthetic responses; and (2) on variation in algal symbiont types during recovery from induced thermal bleaching. In the first experiment, on physiology responses in relation to photosynthesis, 5 polyps of each of the 2 corallimorpharian species were photoacclimated in outdoor aquaria for 1 mo using layers of plastic netting for shade in each of 3 treatments ( $\mathrm{N}=15$ polyps, total of each species): (1) high light levels (HL), $30 \%$ shade with a maximum midday irradiance of $\sim 1160 \mu \mathrm{mol}$ photons $\mathrm{m}^{-2} \mathrm{~s}^{-1}$, equivalent to irradiance at $5 \mathrm{~m}$ depth; (2) medium light levels (ML), $70 \%$ shade with maximum irradiance of $\sim 615 \mu \mathrm{mol}$ photons $\mathrm{m}^{-2}$ $\mathrm{s}^{-1}$, equivalent to irradiance at $10 \mathrm{~m}$ depth; and (3) low light levels (LL), $90 \%$ shade with a maximum midday irradiance of $\sim 165 \mu \mathrm{mol}$ photons $\mathrm{m}^{-2} \mathrm{~s}^{-1}$, equivalent to irradiance at $20 \mathrm{~m}$ depth (as per Kuguru et al. 2007).

A separate outdoor treatment was set up under an overhanging roof (not exposed to direct sunlight), which created a deep-shade treatment (DS), 95\% shade with a maximum midday irradiance of $\sim 85 \mu \mathrm{mol}$ photons $\mathrm{m}^{-2} \mathrm{~s}^{-1}$, equivalent to irradiance at $\sim 40 \mathrm{~m}$ depth. These treatments mimicked irradiance levels encompassing most of the depth range of individuals of these 2 species (Chadwick-Furman \& Spiegel 2000, Kuguru et al. 2007). Irradiances were measured using a quantum sensor (LI-190SA, LiCor) connected to a data logger (LI-1400, LiCor). During the experimental period, temperature loggers (HOBO Temperature Pro, Onset Computers) revealed that the flowing seawater in the laboratory treatments was similar in temperature to ambient temperatures on the adjacent coral reef at $5 \mathrm{~m}$ depth $\left(24\right.$ to $\left.25^{\circ} \mathrm{C}\right)$. The water within each treatment was thoroughly mixed, using small aquarium pumps $\left(600 \mathrm{l} \mathrm{h}^{-1}\right)$. After the first $30 \mathrm{~d}$ of acclimation to these laboratory conditions, the chl a fluorescence of each polyp was measured daily, as described above, for the next $15 \mathrm{~d}$. At the end of the experiment, zooxanthellae abundances and chl a concentrations were quantified for each polyp, as stated above.

In the second laboratory experiment, polyps of Rhodactis rhodostoma were exposed to thermal stress to determine whether their algal symbiont types represented remnants or were shuffled after exposure to thermal-induced bleaching (Kuguru et al. 2007). Understanding whether or not corals have the flexibility to change their complement of symbionts to adapt 
to changing climate is an important goal in reef ecology studies. In this experiment, 4 polyps of $R$. rhodostoma were exposed to high temperature $\left(32^{\circ} \mathrm{C}\right)$ for a period of $2 \mathrm{wk}$ in a $20 \mathrm{l}$ aquarium, and exhibited evidence of bleaching (as per Kuguru et al. 2007). In addition, 4 polyps were kept in a separate $20 \mathrm{l}$ aquarium and subjected to ambient seawater temperature of $26^{\circ} \mathrm{C}$ for the same duration. Each aquarium was supplied with a separate through-flow of seawater at a rate of $60 \mathrm{l} \mathrm{h}^{-1}$ (Kuguru et al. 2007). The $26^{\circ} \mathrm{C}$ treatment mimicked the mean summer temperature in Eilat on the shallow reef (Loya 1985). The high temperature treatment of $32^{\circ} \mathrm{C}$ was a few degrees above the maximum summer temperature in very shallow water $\left(28^{\circ} \mathrm{C}\right)$, and was selected to mimic a possible warming event in this region. Treatment (high temperature) and control (ambient temperature) polyps were shaded by layers of plastic netting that provided maximum irradiance of $\sim 615 \mu \mathrm{mol}$ photons $\mathrm{m}^{-2} \mathrm{~s}^{-1}$, equivalent to that at $10 \mathrm{~m}$ depth on the coral reef. After $2 \mathrm{wk}$, temperature in the high temperature treatment was lowered to ambient level and all polyps were maintained for an additional 12 mo in outdoor aquaria. Chl a fluorescence measurements were performed both during the $2 \mathrm{wk}$ treatment period and 3 mo later. DNA samples were isolated immediately after the 2 wk of treatment, and at intervals of 3,6, and 12 mo after the experiment, to determine any long-term changes in zooxanthellae identity during the period of recovery from bleaching. During the first 3 mo of this experiment, both aquaria were connected to an inlet pipe that drew water from $4 \mathrm{~m}$ depth on the adjacent coral reef. Later, the pipe (with new pipes) was extended and drew water from $30 \mathrm{~m}$. The inlet was changed because the IUI management learned that during summer, the water temperatures in laboratory aquaria were very high. To avoid the cost of using chillers, the pipes were extended to deeper water. Thus, we expected the polyps in our laboratory treatments to shuffle Symbiodinium types after extension of the pipe to $30 \mathrm{~m}$, as populations of Symbiodinium clade $\mathrm{D}$ occur in corallimorpharians at depths $>20$ m (Kuguru et al. 2007).

Molecular analysis of Symbiodinium ITS2 types. Molecular identification of Symbiodinium types within each major clade associated with polyps of Rhodactis rhodostoma and Discosoma unguja was determined using internal transcribed spacer region (ITS2) sequences of ribosomal RNA genes (LaJeunesse 2001, 2002). The ITS2 genetic marker provides adequate resolution among ecologically distinct forms of Symbiodinium, while being sufficiently conserved to enable comparison among communities (LaJeunesse 2001). In addition, the resulting ITS2 diversity represents the natural biological variation and the fine-scale ITS2 may find a parallel in symbiotic functionality differences (LaJeunesse 2001). Total algal nucleic acids were extracted from the tissues of all corallimorpharian polyps used in the above field and laboratory experiments, according to Coffroth et al. (1992). The algal extracts were then lysed in $2 \times$ CTAB (trimethyl ammonium bromide). Total DNA was extracted twice in phenol:chloroform:isoamyl alcohol (24:24:1) and chloroform:isoamyl alcohol (24:1). The DNA was precipitated in $95 \%$ ethanol and then washed in $70 \%$ ethanol before being left to air dry at ambient temperature.

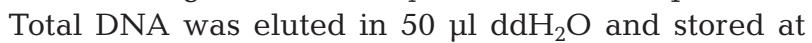
$-20^{\circ} \mathrm{C}$ (Coffroth et al. 1992). The internal transcribed spacer ITS2 (rDNA) region of the Symbiodinium genome was amplified after LaJeunesse (2001), with a slight modification of higher annealing temperature and elimination of the clamp portion of the primer. Due to this modification, a temperature gradient test was done and $57^{\circ} \mathrm{C}$ found to be the best annealing temperature. The forward primer ITSintfor2, 5'GAATTGCAGA ACTCCGTG 3', and the reverse ITSintrev2, 5' GGGATCCAT ATGCTTAAGTTCAGC GGGT 3', were used for a PCR under the following cycling conditions: denaturing step of $4 \mathrm{~min}$ at $94^{\circ} \mathrm{C}, 30$ cycles of $60 \mathrm{~s}$ at $94^{\circ} \mathrm{C}, 60 \mathrm{~s}$ at $57^{\circ} \mathrm{C}$, and $60 \mathrm{~s}$ at $72^{\circ} \mathrm{C}$, with extension of $5 \mathrm{~min}$ at $72^{\circ} \mathrm{C}$. PCR products were checked on $1.5 \%$ agarose gels stained with ethidium bromide. PCR products were purified from the gel using the QIAquick gel extraction kit (QIAQGEN, catalogue no. 28706), according to manufacturer's instructions, prior to sending for sequence. PCR products were sequenced directly in both directions.

All sequences were blasted in the GenBank database of the National Center for Biotechnology Information (NCBI) to see if they signified ITS rDNA Symbiodinuim. Sequence similarities and differences were identified after they were aligned and improved manually using BIOEDIT 5.0.9 sequence alignment software (Hall 1999). Consensus sequences of the Symbiodinium ITS2 rDNA types were identified from identical previously published sequences in GenBank for the same types, ITS2 Type C1 (AF333515, F333518, LaJeunesse 2001; EU074958, Thornhill et al. 2006), Type D1a (AF499802, AY686649, and AY686650, LaJeunesse 2002, LaJeunesse et al. 2004; EU074906, Thornhill et al. 2006) and Type D4 (DQ865214). The alignment dataset is available on request from the corresponding author.

Statistical analyses. Two-way ANOVAs were used to assess variation in the abundance of corallimorpharian polyps, zooxanthellae abundances, chl a pigment concentration, $\mathrm{Q}_{\mathrm{m}}$ and $F_{\mathrm{v}} / F_{\mathrm{m}}$ of polyps with species and depth in the field. Two-way ANOVAs were also used to analyze the effects of light on zooxanthellae abundance, chlorophyll pigment concentration, and $\mathrm{Q}_{\mathrm{m}}$ in the laboratory physiological experiments. Effects of 
light on daily values of $F_{\mathrm{v}} / F_{\mathrm{m}}$ were determined using repeated-measure 2-way ANOVAs, with time as the repeated measure. In the laboratory experiment on effects of thermal stress, variation in $F_{\mathrm{v}} / F_{\mathrm{m}}$ and UVabsorbing compound at different depths was analyzed using a $t$-test. Proportional data were arcsine-transformed prior to statistical analyses. All data met assumptions of homogeneity of variances (Levene's test) and normality (normal probability plots). Equality of variances among treatments in the repeated-measure ANOVA was determined using Mauchly's test of sphericity $(\hat{\varepsilon})$. Violation of sphericity was adjusted according to the Green-Geisser correction (Scheiner \& Gurevitch 2001). Significant differences among treatment groups were determined post-hoc using Student-Newman-Keuls (SNK) tests.
Table 2. Rhodactis rhodostoma and Discosoma unguja. Two-way ANOVAs on photosynthetic parameters with depth on coral reefs at Eilat, northern Red Sea. ${ }^{* *} \mathrm{p}<0.01 ;{ }^{* * *} \mathrm{p}<0.001 ; \mathrm{ns}=$ not significant

\begin{tabular}{|c|c|c|c|c|c|}
\hline $\begin{array}{l}\text { Photosynthetic } \\
\text { parameter }\end{array}$ & $\begin{array}{c}\text { Source } \\
\text { of variation }\end{array}$ & $\mathrm{df}$ & MS & $F$ & $\mathrm{p}$ \\
\hline $\begin{array}{l}\text { Zooxanthellae } \\
\text { abundance }\end{array}$ & $\begin{array}{c}\text { Depth } \\
\text { Species } \\
\text { Depth } \times \text { Species } \\
\text { Error }\end{array}$ & $\begin{array}{r}2 \\
1 \\
2 \\
24\end{array}$ & $\begin{array}{l}141.22 \times 10^{10} \\
1.40 \times 10^{10} \\
6.43 \times 10^{10} \\
28.00 \times 10^{10}\end{array}$ & $\begin{array}{l}5.019 \\
0.049 \\
0.228\end{array}$ & $\begin{array}{l}{ }^{* *} \\
\mathrm{~ns} \\
\mathrm{~ns}\end{array}$ \\
\hline $\begin{array}{l}\text { Chlorophyll } \\
\text { concentration }\end{array}$ & $\begin{array}{c}\text { Depth } \\
\text { Species } \\
\text { Depth } \times \text { Species } \\
\text { Error }\end{array}$ & $\begin{array}{r}2 \\
1 \\
2 \\
24\end{array}$ & $\begin{array}{c}196.80 \\
454.20 \\
47.80 \\
118.60\end{array}$ & $\begin{array}{l}2.178 \\
5.026 \\
0.528\end{array}$ & $\begin{array}{l}{ }^{* *} \\
\mathrm{~ns} \\
\mathrm{~ns}\end{array}$ \\
\hline Excitation pressure & $\begin{array}{c}\text { Depth } \\
\text { Species } \\
\text { Depth } \times \text { Species } \\
\text { Error }\end{array}$ & $\begin{array}{r}2 \\
1 \\
2 \\
24\end{array}$ & $\begin{array}{l}0.052 \\
0.006 \\
0.002 \\
0.006\end{array}$ & $\begin{array}{l}9.011 \\
1.017 \\
0.391\end{array}$ & $\begin{array}{l}* * * \\
\mathrm{~ns} \\
\mathrm{nS}\end{array}$ \\
\hline$F_{\mathrm{v}} / F_{\mathrm{m}}$ & $\begin{array}{c}\text { Depth } \\
\text { Species } \\
\text { Depth } \times \text { species } \\
\text { Error }\end{array}$ & $\begin{array}{r}2 \\
1 \\
2 \\
24\end{array}$ & $\begin{array}{l}0.008 \\
0.008 \\
0.006 \\
0.005\end{array}$ & $\begin{array}{l}1.506 \\
1.487 \\
1.276\end{array}$ & $\begin{array}{l}\mathrm{ns} \\
\mathrm{ns} \\
\mathrm{ns}\end{array}$ \\
\hline $\begin{array}{l}\text { Chlorophyll } \\
\text { concentration per } \\
\text { zooxthanthella cell }\end{array}$ & $\begin{array}{c}\text { Depth } \\
\text { Species } \\
\text { Depth } \times \text { Species } \\
\text { Error }\end{array}$ & $\begin{array}{r}2 \\
1 \\
2 \\
24\end{array}$ & $\begin{array}{c}8.583 \\
6.196 \\
12.689 \\
14.705\end{array}$ & $\begin{array}{l}0.583 \\
0.421 \\
0.862\end{array}$ & $\begin{array}{l}\text { ns } \\
\text { ns } \\
\text { ns }\end{array}$ \\
\hline
\end{tabular}

\section{RESULTS}

Field surveys showed that polyps of the 2 corallimorpharian species had inverse distributional patterns with depth on the coral reef (Table 1, Fig. 1). The abundance of polyps of Rhodactis rhodostoma decreased significantly with depth, while that of Discosoma unguja increased significantly with depth, down to $\sim 20 \mathrm{~m}$ (Fig. 1). R. rhodostoma was much more abundant than $D$. unguja in shallow areas, but the reverse was true on the deep reef slope (Fig. 1).

Field transplantation of corallimorpharian explants at 3 different depths revealed that both the abundance of zooxanthellae and the concentration of chl $a$ within transplanted polyps of both Rhodactis rhodostoma and Discosoma unguja increased significantly along the depth gradient (Table 2, Fig. 2A,B). However, the

Table 1. Rhodactis rhodostoma and Discosoma unguja. Twoway ANOVA on abundance with depth on coral reefs at Eilat, northern Red Sea. ${ }^{* * *} p<0.001$

\begin{tabular}{|lrrrr|}
\hline Source of variation & df & \multicolumn{1}{c|}{ MS } & \multicolumn{1}{c|}{$F$} & $\mathrm{p}$ \\
\hline Depth & 2 & 23.77 & 22.41 & ${ }^{* * *}$ \\
Species & 1 & 160.16 & 150.98 & ${ }^{* * *}$ \\
Depth $\times$ Species & 2 & 93.95 & 88.57 & ${ }^{* * *}$ \\
Error & 18 & 1.06 & & \\
\hline
\end{tabular}

amount of chl a per zooxanthellae cell remained constant across depth (Table 2, Fig. 2C). The excitation pressure as measured via chl a fluorescence variability of PSII $\left(\mathrm{Q}_{\mathrm{m}}\right)$ decreased significantly with depth in both species (Table 2, Fig. 2D), while the maximum quantum yield $\left(F_{\mathrm{v}} / F_{\mathrm{m}}\right)$ did not vary significantly (Table 2 , Fig. 2E). Overall, zooxanthellae abundance, chl a concentration, chl a per cell, excitation pressure on PSII $\left(\mathrm{Q}_{\mathrm{m}}\right)$, and maximum quantum yield $\left(F_{\mathrm{v}} / F_{\mathrm{m}}\right)$ did not dif-

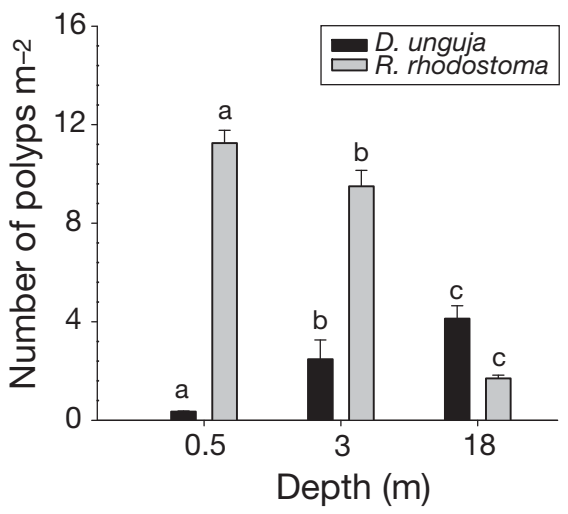

Fig. 1. Rhodactis rhodostoma and Discosoma unguja. Variation in abundance with depth on a coral reef at Eilat, northern Red Sea. Data are presented as mean \pm SE of polyp abundance in twenty $1 \mathrm{~m}^{2}$ quadrats examined at each depth. Depths with different superscript letters are significantly different at $\mathrm{p}<0.05$ (Student-Newman-Keuls post hoc tests following ANOVA analysis, see 'Results' for details) 

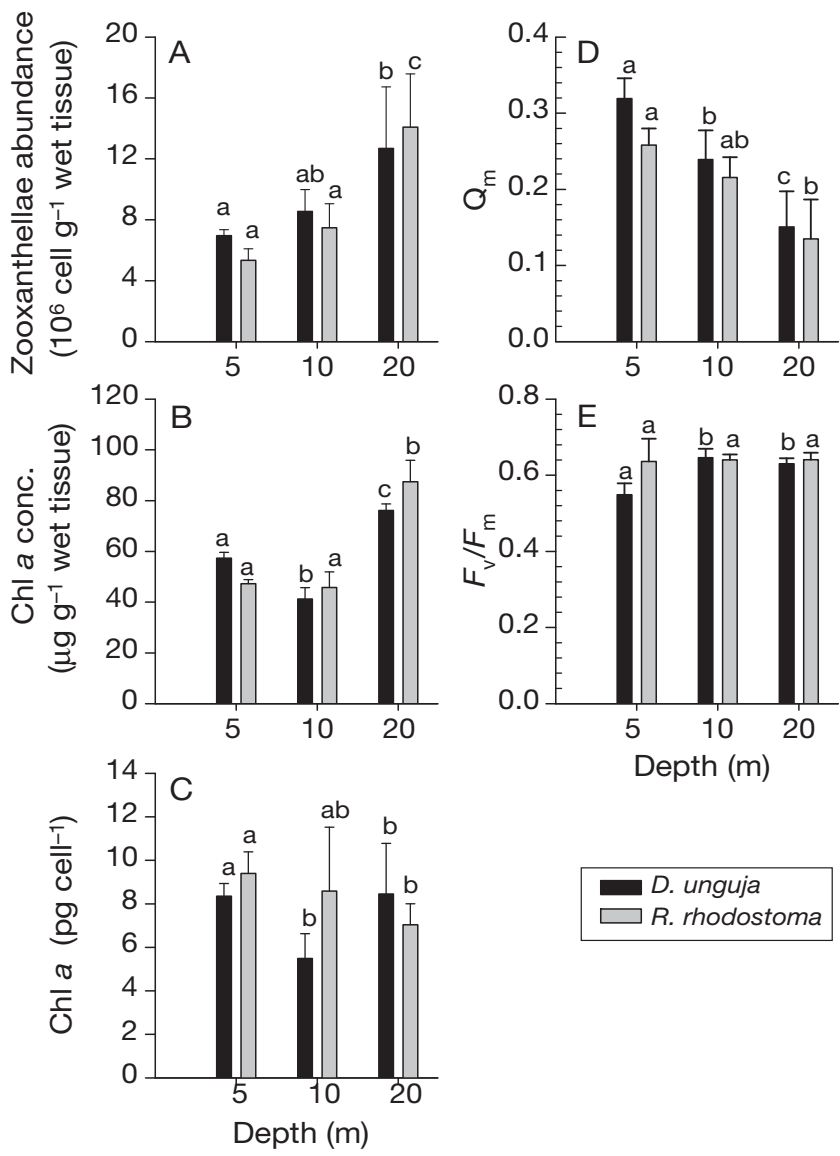

Depth $(\mathrm{m})$

D. unguja $\square$ R. rhodostoma

Fig. 2. Rhodactis rhodostoma and Discosoma unguja. Variation in photosynthetic parameters among depths in transplanted polyps: (A) zooxanthellae abundance, (B) chl a concentration, (C) chl a concentration per cell, (D) excitation pressure over PSII $\left(\mathrm{Q}_{\mathrm{m}}\right)$ and $(\mathrm{E})$ maximum quantum yield $\left(F_{\mathrm{v}} / F_{\mathrm{m}}\right)$. Data are means $\pm \mathrm{SE}, \mathrm{n}=5$ polyps of each species examined per depth. Depths with different superscript letters are significantly different at $\mathrm{p}<0.05$ (Student-Newman-Keuls post hoc tests following ANOVA analysis, see 'Results' for details)

fer significantly between the 2 species in the field (Table 2, Fig. 2).

In the laboratory experiment on impacts of irradiance level on photosynthetic parameters, both zooxanthellae abundance and chl a concentration decreased with irradiance in both species (Table 3, Fig. 3A,B). As in the field, zooxanthellae abundance and chlorophyll concentration did not differ significantly between polyps of Rhodactis rhodostoma and Discosoma unguja (Table 3). However, chl a per cell decreased at high irradiance for both species (Table 3, Fig. 3C), contrary to the pattern in polyps under field conditions.

The pattern of excitation pressure of PSII was similar between laboratory and field treatments (compare Figs. 2D \& 3D). However, $\mathrm{Q}_{\mathrm{m}}$ was significantly higher in Discosoma unguja than in Rhodactis rhodostoma in all laboratory treatments (Table 3, Fig. 3D). In the lab- oratory, $F_{\mathrm{v}} / F_{\mathrm{m}}$ was significantly higher for polyps of $R$. rhodostoma at LL and ML compared to D. unguja. However $R$. rhodostoma demonstrated significantly lower values of $F_{\mathrm{v}} / F_{\mathrm{m}}$ at HL (Table 3). Post hoc tests revealed that HL caused a significant reduction in zooxanthellae abundance, chl a concentration per cell, and $F_{\mathrm{v}} / F_{\mathrm{m}}$ in both species (Fig. 3). Some photosynthetic parameters of $D$. unguja, such as $\mathrm{Q}_{\mathrm{m}}$ and $F_{\mathrm{v}} / F_{\mathrm{m}}$, were more sensitive to light exposure than were those of $R$. rhodostoma (SNK: $\mathrm{p}<0.01$, Table 3 ).

Exposure to HL reduced the $F_{\mathrm{v}} / F_{\mathrm{m}}$ values of all polyps (Fig. 4), but there was a sharp drop of $F_{\mathrm{v}} / F_{\mathrm{m}}$ by the second day in Discosoma unguja polyps relative to
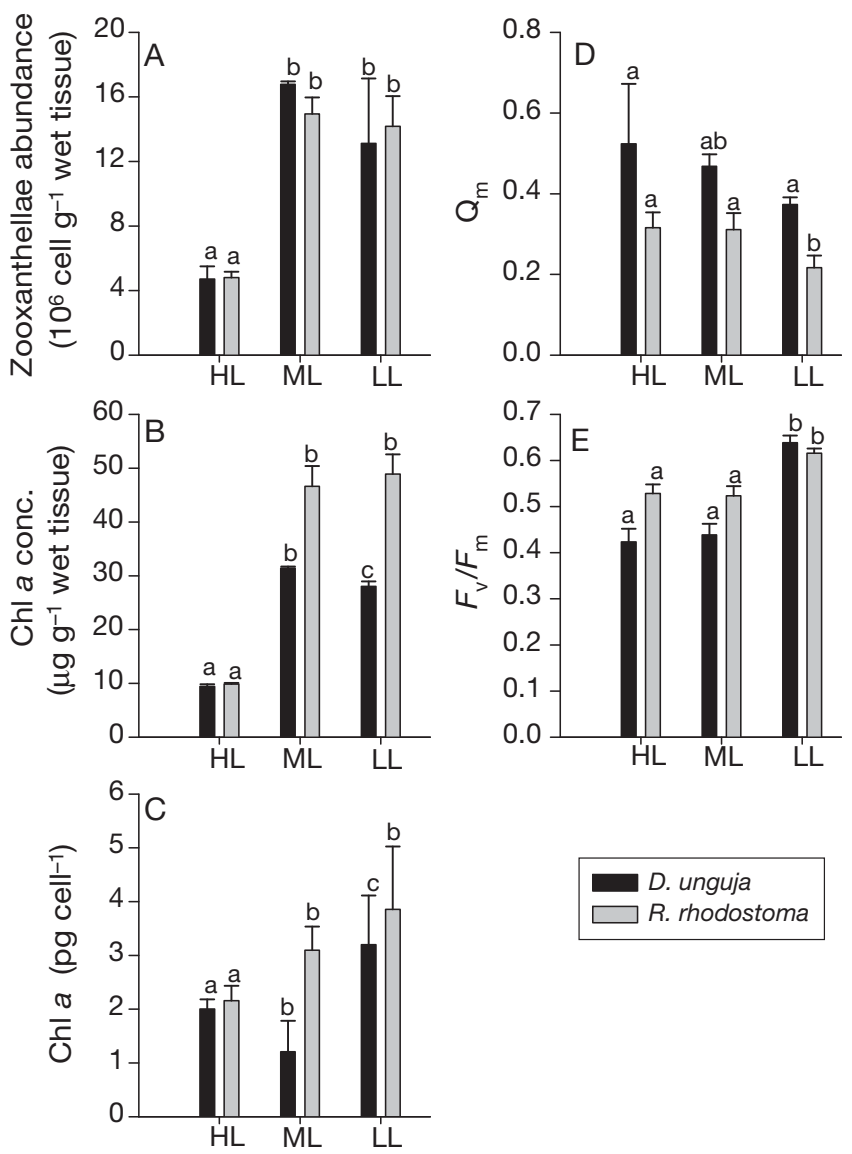

Fig. 3. Rhodactis rhodostoma and Discosoma unguja. Variation in photosynthetic parameters among laboratory light treatments: (A) zooxanthellae abundance, (B) chl a concentration, (C) chl a concentration per cell, (D) excitation pressure over PSII $\left(\mathrm{Q}_{\mathrm{m}}\right)$, and $(\mathrm{E})$ maximum quantum yield $\left(F_{\mathrm{v}} / F_{\mathrm{m}}\right)$. Data shown are after $16 \mathrm{~d}$ exposure to 3 laboratory treatments: high light levels (HL, daily maximum $1160 \mu \mathrm{mol}$ photons $\mathrm{m}^{-2} \mathrm{~s}^{-1}$ ), medium light levels (ML, daily maximum $615 \mu \mathrm{mol}$ photons $\mathrm{m}^{-2} \mathrm{~s}^{-1}$ ), and low light levels ( $\mathrm{LL}$, daily maximum $350 \mu \mathrm{mol}$ photons $\mathrm{m}^{-2} \mathrm{~s}^{-1}$ ). Data are mean $\pm \mathrm{SE}, \mathrm{n}=5$ polyps per treatment. Treatments with different superscript letters are significantly different at $\mathrm{p}<0.05$ (Student-Newman-Keuls post-hoc tests following ANOVA analysis, see 'Results' for details) 
Table 3. Rhodactis rhodostoma and Discosoma unguja. Two-way ANOVAs on photosynthetic parameters with irradiance levels under laboratory conditions after $15 \mathrm{~d}$ light treatments at Eilat, northern Red Sea. ${ }^{* *} \mathrm{p}<0.01 ;{ }^{* * *} \mathrm{p}<0.001$; ns $=$ not significant

\begin{tabular}{|lcrcrc|}
\hline $\begin{array}{l}\text { Photosynthetic } \\
\text { parameter }\end{array}$ & $\begin{array}{c}\text { Source } \\
\text { of variation }\end{array}$ & df & MS & $F$ & p \\
\hline Zooxanthellae & Light & 2 & $6.20 \times 10^{14}$ & 26.94 & ${ }^{* * *}$ \\
abundance & Species & 1 & $0.50 \times 10^{14}$ & 2.19 & $\mathrm{~ns}$ \\
& Light $\times$ Species & 2 & $0.68 \times 10^{14}$ & 2.95 & $\mathrm{~ns}$ \\
Chlorophyll & Error & 18 & $0.23 \times 10^{14}$ & & \\
concentration & Light & 2 & 454.20 & 5.026 & ${ }^{* * *}$ \\
& Species & 1 & 196.80 & 2.178 & $\mathrm{~ns}$ \\
& Light $\times$ Species & 2 & 47.80 & 0.528 & $\mathrm{~ns}$ \\
Excitation pressure & Error & 18 & 51.230 & & \\
& Light & 2 & 0.015 & 0.748 & $\mathrm{~ns}$ \\
& Species & 1 & 0.100 & 5.133 & ${ }^{* *}$ \\
$F_{\mathrm{v}} / F_{\mathrm{m}}$ & Light $\times$ Species & 2 & 0.002 & 0.081 & $\mathrm{~ns}$ \\
& Error & 18 & 0.010 & & \\
& Light & 2 & 0.076 & 34.87 & $* * *$ \\
& Species & 1 & 0.023 & 10.73 & ${ }^{* * *}$ \\
Chl $a$ concentration & Light $\times$ Species & 2 & 0.012 & 5.62 & $* * *$ \\
per zooxthanthella & Error & 24 & 0.002 & & \\
cell & Light & 2 & 193.92 & 36.929 & ${ }^{* * *}$ \\
& Species & 1 & 15.46 & 2.943 & $\mathrm{~ns}$ \\
& Light $\times$ Species & 2 & 9.03 & 1.718 & $\mathrm{~ns}$ \\
& Error & 18 & 5.25 & & \\
\hline
\end{tabular}

treatment in D. unguja continued throughout the rest of the experiment relative to $R$. rhodostoma (Table 4, Fig. 4). In contrast, the shade (LL) treatment produced no reduction in $F_{\mathrm{v}} / F_{\mathrm{m}}$ in either species.

Bioaccumulation of UV-absorbing compound (S320, Kinzie, 1993) was significantly different between Rhodactis rhodostoma and Discosoma unguja (2-way ANOVA, $\mathrm{F}_{1,16}=18.15$, $\mathrm{p}<0.001)$. Polyps of both species collected at $4 \mathrm{~m}$ significantly bioacumulated more UV-absorbing substance in their host tissues than did those collected at $20 \mathrm{~m}$ (2-way ANOVA, $F_{1,16}=$ 435.53, p < 0.001, Fig. 5). R. rhodostoma and $D$. unguja at $4 \mathrm{~m}$ bioaccumulated more UV-absorbing compound 1.3- and 1.35-fold, respectively, than their respective individual members at $20 \mathrm{~m}$. In both shallow and deep waters, the UV-absorbing substances appeared mostly to be concentrated in the host cnidarian tissues in both species of corallimorpharians (Fig. 5).

Rhodactis rhodostoma polyps. An even larger reduction of $F_{\mathrm{v}} / F_{\mathrm{m}}$ in $D$. unguja (22\%) compared to $R$. rhodostoma (15\%) was observed on the fifth day of acclimation under HL. By the sixth day of acclimation, both species in the HL treatment began to show recovery in their $F_{\mathrm{v}} / F_{\mathrm{m}}$ values. However, the loss of $F_{\mathrm{v}} / F_{\mathrm{m}}$ in the HL

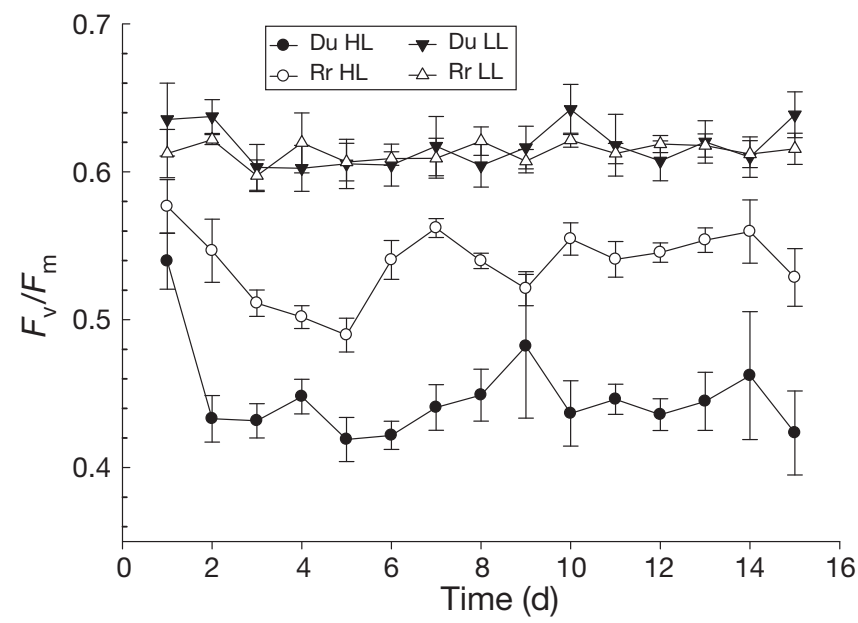

Fig. 4 Rhodactis rhodostoma (Rr) and Discosoma unguja (Du). Variation in maximum quantum yields $\left(F_{\mathrm{v}} / F_{\mathrm{m}}\right)$ of polyps over time among light treatments, under laboratory conditions. Data show values over $16 \mathrm{~d}$ in experimental light treatments: high light levels (HL, daily maximum $1160 \mu \mathrm{mol}$ photons $\mathrm{m}^{-2} \mathrm{~s}^{-1}$ ) and low light levels (LL, daily maximum $350 \mu \mathrm{mol}$ photons $\mathrm{m}^{-2} \mathrm{~s}^{-1}$ ). Data are mean $\pm S E, n=5$ polyps per treatment
ITS2 rDNA sequence analysis revealed that polyps of Rhodactis rhodostoma in all light treatments under laboratory conditions contained Symbiodinium Type C1 (Table 5). In contrast, Discosoma unguja contained Symbiodinium Type C1 and D1a + D4 in LL, and Type C1 both in HL and DS light treatments, similar to the Symbiodinium types they contain under the same light levels in the field.

Prior to the start of the reciprocal transplant experiment, all polyps of both species contained only Type $\mathrm{C} 1$ algal symbionts in shallow areas (5 $\mathrm{m}$ depth), and

Table 4. Rhodactis rhodostoma and Discosoma unguja. Repeated measures 2-way ANOVA, with time as the repeated measure of variation in photosynthetic yield (maximum quantum yield, $F_{\mathrm{v}} / F_{\mathrm{m}}$ ) with level of experimental irradiance under laboratory conditions. ${ }^{* *} \mathrm{p}<0.01$; $^{* * *} \mathrm{p}<0.001$; ns $=$ not significant

\begin{tabular}{|lrrrr|}
\hline Source of variation & df & MS & $F$ & $\mathrm{p}$ \\
\hline Light & 1 & 1.149 & 216.7 & ${ }^{* * *}$ \\
Species & 1 & 0.143 & 26.9 & ${ }^{* * *}$ \\
Light $\times$ Species & 1 & 0.169 & 31.8 & ${ }^{* * *}$ \\
Error & 16 & 0.005 & & \\
Time & 14 & 0.004 & 3.6 & ${ }^{* * *}$ \\
Time $\times$ Species & 14 & 0.001 & 1.1 & $\mathrm{~ns}$ \\
Time $\times$ Light & 14 & 0.002 & 2.1 & ${ }^{* *}$ \\
Time $\times$ Species $\times$ Light & 14 & 0.001 & 1.2 & $\mathrm{~ns}$ \\
Error & 224 & 0.001 & & \\
\hline
\end{tabular}




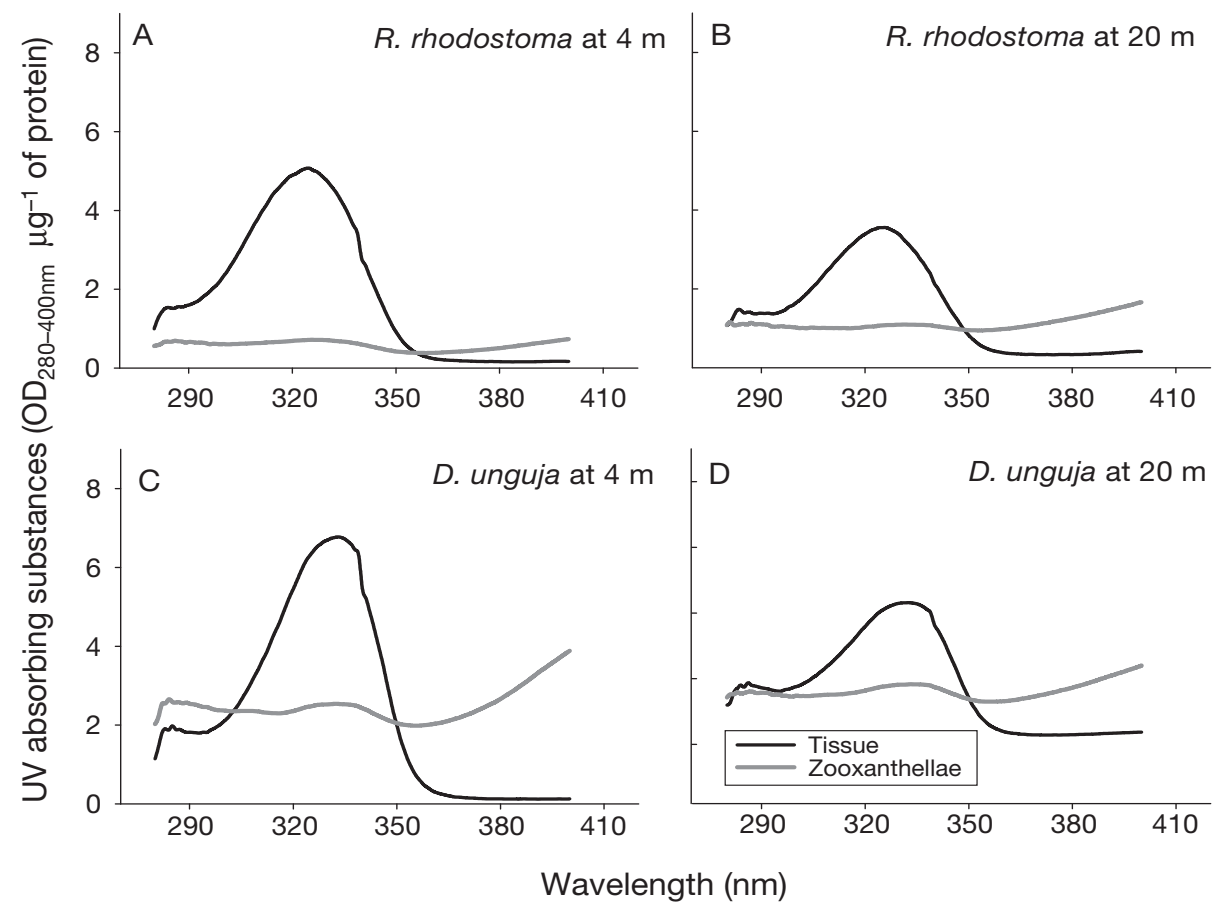

Fig. 5. Rhodactis rhodostoma and Discosoma unguja. UV-absorbing substance (UAS) absorption spectra of host and zooxanthellae cells in polyps of $(\mathrm{A}, \mathrm{B}) \mathrm{R}$. rhodostoma and $(\mathrm{C}, \mathrm{D}) \mathrm{D}$. unguja at $4 \mathrm{~m}$ and $20 \mathrm{~m}$ on the coral reef at Eilat, northern Red Sea

both Type C1 and Type D1a in deep areas (20 m depth, Table 6). Three mo after reciprocal transplantation, the polyps of both species that were moved from shallow to deep shuffled their Type C1 algae to D1a, in addition to retaining their Type $\mathrm{C} 1$ algae. Those that were transferred from deep to shallow shuffled their Symbiodinium Type D1a and remained with only Symbiodinium Type C1 (Table 6). Six mo later, after being returned to their original depths, the individuals of Discosoma unguja shuffled their symbiont type to D1a at depth in addition to retaining Type $\mathrm{C} 1$, but the individuals of Rhodactis rhodostoma did not. Again, members of both species, when relocated to shallow waters,

Table 5. Symbiodinium diversity in Rhodactis rhodostoma and Discosoma unguja $(\mathrm{n}=4)$ after $1 \mathrm{mo}$ in high light (HL), low light (LL), and shaded (SH) treatments under laboratory conditions at the IUI, Eilat, northern Red Sea. Symbiodinium subclade identity was determined by direct sequence alignment data of internal transcribed spacer (ITS2) rDNA. Numbers in parentheses represent sample sizes

\begin{tabular}{|c|c|c|c|}
\hline Treatment & $\begin{array}{c}\text { Light } \\
\text { condition } \\
\text { (\% shade) }\end{array}$ & $\begin{array}{r}\text { Zooxanthella } \\
\text { identi } \\
\text { R. rhodostoma }\end{array}$ & $\begin{array}{l}\text { ae genetic } \\
\text { ity } \\
\text { D. unguja }\end{array}$ \\
\hline High light (HL) & 40 & C1 (4) & C1 (4) \\
\hline Low light (LL) & 90 & $\mathrm{C} 1(4)$ & $\begin{array}{c}\text { C1 (3) } \\
\text { D1a + D4 }\end{array}$ \\
\hline Deep shade (DS) & 97.5 & C1 (4) & C1 (4) \\
\hline
\end{tabular}

shuffled their D1a type symbionts to Type C1. Finally, the control polyps all retained only Type C1 symbionts in shallow areas and both Type C1 and Type D1a at depth (Table 6). Thus, the corallimorpharians always had a higher ratio for both Type C1 and Type D1a at depth, and only a higher ratio of Type C1 in shallow areas, except for the $R$. rhodostoma individuals, which did not shuffle to D1a at depth during the final return to their original depth.

Polyps of Rhodactis rhodostoma exposed to high temperature $\left(32^{\circ} \mathrm{C}\right)$ bleached (as also seen in Fig. $4 \mathrm{~A}, \mathrm{~B}$ in Kuguru et al. 2007), while the control treatment at ambient temperature $\left(26^{\circ} \mathrm{C}\right)$ did not $(t$-test, $\mathrm{p}<0.0001)$. Interestingly, during all 4 sampling periods, including during recovery from bleaching ( $t$-test, $p=0.085)$ when the temperature was lowered to ambient, the polyps of $R$. rhodostoma maintained the same remnant Symbiodinium Type C1 (Table 7). However, later in the year, some polyps of $R$. rhodostoma maintained at ambient temperature $\left(26^{\circ} \mathrm{C}\right)$ also shuffled to Symbiodinium Type D1a (Table 7).

\section{DISCUSSION}

We show that the corallimorpharians Rhodactis rhodostoma and Discosoma unguja have contrasting distributional patterns on coral reefs, which appear to be explained in part by variation in their mechanisms of 
Table 6. Variation in Symbiodinium algal types associated with the corallimorpharians Rhodactis rhodostoma and Discosoma unguja during a field transplantation experiment. Algae were typed prior to transplantation, 3 mo after transplanting the experimental polyps to opposite depths $(20$ and $5 \mathrm{~m}$ ), and 6 mo after returning the experimental polyps back to their original depths (5 and $20 \mathrm{~m}$ ) on coral reefs at Eilat, northern Red Sea. Control polyps were maintained at their original depths of collection, through-

out the experiment. Numbers in parentheses represent sample sizes in numbers of corallimorpharian polyps examined

\begin{tabular}{|c|c|c|c|c|c|}
\hline \multirow{2}{*}{$\begin{array}{l}\text { Treatment } \\
\text { species }\end{array}$} & \multirow[t]{2}{*}{ Corallimorpharian } & \multicolumn{2}{|c|}{ Experimental treatment } & \multicolumn{2}{|c|}{ Control treatment } \\
\hline & & $5 \mathrm{~m}$ & $20 \mathrm{~m}$ & $5 \mathrm{~m}$ & $20 \mathrm{~m}$ \\
\hline \multirow[t]{2}{*}{ Before transplantation } & R. rhodostoma & C1 (4) & $\mathrm{C} 1(3), \mathrm{D} 1 \mathrm{a}$ & $\mathrm{C} 1(4)$ & C1(3), D1a \\
\hline & D. unguja & C1 (4) & C1 (3), D1a & C1 (4) & C1(3), D1a \\
\hline \multirow{2}{*}{$\begin{array}{l}3 \text { mo after transplantation to opposite depths } \\
(20 \text { and } 5 \mathrm{~m})\end{array}$} & R. rhodostoma & $\mathrm{C} 1(4)$ & C1 (3), D1a & $\mathrm{C} 1(4)$ & C1(3), D1a \\
\hline & D. unguja & C1 (4) & C1 (3), D1a & $\mathrm{C} 1(4)$ & C1(3), D1a \\
\hline \multirow{2}{*}{$\begin{array}{l}6 \text { mo after return to original depths } \\
(5 \text { and } 20 \mathrm{~m})\end{array}$} & R. rhodostoma & $\mathrm{C} 1(4)$ & $\mathrm{C} 1(4)$ & $\mathrm{C} 1(4)$ & C1(3), D1a \\
\hline & D. unguja & $\mathrm{C} 1(4)$ & $\mathrm{C}(3), \mathrm{D} 1 \mathrm{a}$ & $\mathrm{C} 1(4)$ & C1(3), D1a \\
\hline
\end{tabular}

Table 7. ITS2 rDNA-identified Symbiodinium diversity in experimental polyps of the corallimorpharian Rhodactis rhodostoma ( $\mathrm{n}=4$ ) during bleaching and at 3,6 and 12 mo of recovery after temperature was lowered back to ambient $\left(32^{\circ} \mathrm{C}\right.$ to $\left.26^{\circ} \mathrm{C}\right)$. Polyps were maintained under plastic netting that created $40 \%$ shade throughout the experiment (equivalent to irradiance at $10 \mathrm{~m}$ depth on the adjacent coral reef). Control polyps were kept under the same conditions, but temperature was not experimentally changed and bleaching did not occur

\begin{tabular}{|lc|}
\hline Sampling period & Zooxanthellae genetic identity \\
\hline Control treatment & \\
During bleaching & $\mathrm{C} 1(4)$ \\
3 mo later & $\mathrm{C} 1(3), \mathrm{D} 1 \mathrm{a}(1)$ \\
6 mo later & $\mathrm{C} 1(2), \mathrm{D} 1 \mathrm{a}(2)$ \\
1 yr later & $\mathrm{C} 1(2), \mathrm{D} 1 \mathrm{a}(2)$ \\
Experimental treatment & \\
During bleaching & $\mathrm{C} 1(4)$ \\
3 mo later & $\mathrm{C} 1(4)$ \\
6 mo later & $\mathrm{C} 1(4)$ \\
1 yr later & $\mathrm{C} 1(4)$ \\
\hline
\end{tabular}

physiological response to irradiance (PAR). This is in agreement with the findings of Iglesias-Prieto et al. (2004), Warner et al. (2006) and Mass et al. (2007) in stony coral and those of Kuguru et al. (2007) in corallimorpharia. We identify 4 major mechanisms through which these corallimorpharians respond to changes in the physical environment: (1) polyps regulate the abundance of zooxanthellae in their tissues with depth on the reef (Fig. 2A); (2) the zooxanthellae algal cells modify the concentration of chlorophyll per cell with light intensity (Fig. 3C); (3) host polyps concentrate UV-absorbing compounds in their tissue (Fig. 5); and (4) the photosynthetic apparatus of the algal symbionts dissipates excess light energy at high irradiance (Table 2).

Individuals of both Rhodactis rhodostoma and Discosoma unguja host (shuffled) selectively up-regulated their symbiont types (C1 and D1a) at different depths. Symbiont shuffling (i.e. adjustment in the ratio of an already co-existing symbiont population) represents a mechanism for rapid acclimatization of the holobiont to environmental changes (Baker 2003). When exposed to environmental stress, the corallimorpharian hosts can contain either a single algal type (as does $R$. rhodostoma) or multiple symbiont types that shuffle when subjected to unfavorable environmental conditions (as does $D$. unguja). In addition, the hosts can immediately shuffle back to their original assemblages of symbiont genotypes when favorable conditions are restored. Polyps of $R$. rhodostoma, which hosts single symbiont types, demonstrate more resilience and acclimate better to environmental stressors, such as high irradiance and increased temperature relative to those of $D$. unguja. In contrast, individuals of $D$. unguja, which hosts multiple symbiont type assemblage, demonstrate more sensitivity to high irradiance PAR. These findings are in agreement with recent studies in octocoral (Goulet et al. 2005), stony coral (Baker 2003, Little et al. 2004) and sea anemone (Goulet et al. 2005).

The reciprocal distributional patterns of Rhodactis rhodostoma and Discosoma unguja may be caused, in part, by their different abilities to acclimate to variable light fields along the depth gradient of the reef. For many symbiotic anthozoans, including scleractinian corals, photosynthetic compensation for LL is achieved through increased algal pigment content rather than zooxanthellae abundance with depth (Falkowski \& Dubinsky 1981). In contrast, both species of corallimorpharians increased their zooxanthellae density with increasing depth and decreasing light. Higher chlorophyll concentration per cell (Fig. 3C), combined with increased zooxanthellae abundance (Figs. 2A \& 3A) within corallimorpharians in deep areas and in shallow shaded microhabitats, may increase the overall photosynthetically active sites per unit of host tissue (Figs. 2B \& 3B). This has also been suggested for other 
corals across depth ranges (Barnes 1973). Since the polyps of both corallimorpharian species in the present study maintained constant levels of chl a per algal cell in the field (Table 2, Fig. 2C), the algae were able to maintain a constant photosynthetic capacity across depths (Table 2, Fig. 2E). This pattern is similar to that observed by Nir (2006) for the hermatypic coral Seriatopora hystrix at the same study site. In contrast, our finding of a significant increase in chl a per algal cell at LL intensities under laboratory conditions is similar to the pattern observed for the stony coral Stylophora pistillata by Falkowski \& Dubinsky (1981).

The major difference in irradiance between the laboratory and field conditions was in terms of light quality. Levy et al. (2006) measured the light spectrum (both in quantity and quality) on the coral reef at our study site and found that light intensity is attenuated with increased depth or decreased water clarity and the light spectrum shifts towards blue. Thus, we hypothesize that the polyps at depth in our field experiment experienced a narrower spectrum of wavelengths (lower light quality) than did those at LL in the laboratory experiment. This difference may partially explain the different reactions of the polyps to LL between these experiments. Both the corallimorpharian hosts and their algal symbionts can thus sustain their photosynthetic rates at each depth on the reef by controlling the effects of both the quantity and quality of irradiance (Table 2, Fig. 2). The inter- and intraspecific variation in chl a per zooxanthellae cell in both species under laboratory conditions (Table 3, Fig. 3) is most likely governed by a combination of HL intensity with a full spectrum, including more UV and the redto-far-red spectrum that is missing from the natural, deep experimental site. The natural mechanism that governs photosynthetic rates along this depth gradient may respond to the down-regulation of the reaction centers of PSII, and perhaps the absence of the red spectra influences PSI activity and abundance (Kinzie $\&$ Hunter 1987). There may be variation in the accessory pigments that may influence the depth-related light-harvesting capabilities and, indeed, some P680 fluorescence measurements suggest that there was variation in excitation energy with depth (Fig. 2D).

Information regarding the mechanisms employed by the algal symbionts within corallimorpharians to avoid effects of photoinhibition at HL may also be derived from our chl a fluorescence measurements $\left(F_{\mathrm{v}} / F_{\mathrm{m}}\right.$ and $\mathrm{Q}_{\mathrm{m}}$ ). Our observation that both Rhodactis rhodostoma and Discosoma unguja did not vary in $F_{\mathrm{v}} / F_{\mathrm{m}}$ with depth is similar to the pattern observed in 3 species of stony corals (Montastraea faceolata, Porites astreoides and Siderastrea siderea) growing at $8 \mathrm{~m}$ and $25 \mathrm{~m}$ (Warner et al. 2006). The decrease of $F_{\mathrm{v}} / F_{\mathrm{m}}$ in shallow waters that occurs in some other corals indicates chronic pho- toinhibition (Franklin et al. 1996, Winters et al. 2003). The higher $\mathrm{Q}_{\mathrm{m}}$ values in the corallimorpharian polyps examined here in shallow water compared to their counterparts in deeper waters indicate downregulation of photosynthesis (diurnal photoinhibition, Figs. 2 \& 3), because their $F_{\mathrm{v}} / F_{\mathrm{m}}$ values did not concurrently decrease in shallow water. This increased excitation pressure appears to reflect the high midday irradiance in shallow water and not any sort of reduction or closure of reaction centers. Higher $\mathrm{Q}_{\mathrm{m}}$ values, along with lower $F_{\mathrm{v}} / F_{\mathrm{m}}$ values, observed in HL compared to LL treatments, indicated the occurrence of photoinhibition in both species of corallimorpharians at high irradiance.

The mechanisms we observed here for avoidance of photoinhibition at HL appeared to be species-specific. Polyps of Rhodactis rhodostoma dissipated more excess light energy (as indicated by their low $Q_{m}$ values, Table 2) and had higher maximum quantum yields $\left(F_{\mathrm{v}} / F_{\mathrm{m}}\right)$ than did those of Discosoma unguja (Figs. 3D,E \& 4), indicating possible adaptations to a more intense light environment. The sequence of reactions to HL in the laboratory experiment also revealed that polyps of $R$. rhodostoma are better able to resist photodamage due to HL than those of $D$. unguja. While the polyps of both species declined in $F_{\mathrm{v}} / F_{\mathrm{m}}$ values during the initial $5 \mathrm{~d}$ of the experiment as their algae photoacclimated to the increased light, afterwards, the $F_{\mathrm{v}} / F_{\mathrm{m}}$ values of $R$. rhodostoma increased slightly, suggesting that a portion of their photosynthetic reaction centers recovered. On the other hand, $F_{\mathrm{v}} / F_{\mathrm{m}}$ levels for $D$. unguja did not recover but remained at a low, constant value throughout the HL experiment. Previous studies also have shown that corals with symbiotic algae that mitigate HL pressure are more able to tolerate irradianceinduced stress (Maxwell et al. 1995, Iglesias-Prieto \& Trench 1997, Iglesias-Prieto et al. 2004).

The zooxanthellae harbored by cnidarians vary in their photosynthetic abilities and may affect the responses of their hosts to environmental stresses (Goulet et al. 2005). However, in a cnidarian-algal association (Goulet et al. 2005), the physiological entity is the genotypic combination of host and symbiont (holosymbiont) (Iglesias-Prieto \& Trench 1997). Since individuals of both Rhodactis rhodostoma and Discosoma unguja are associated with Symbiodinium Type C1 in HL treatment (Table 5), we hypothesize that the differences in photoacclimation ability to HL were host-mediated. The morphology and physiology of symbiotic invertebrates can vary widely among species (Gates \& Edmunds 1999), thus a given Symbiodinium type may experience very dissimilar environments, depending on the symbiotic invertebrate species that it inhabits (Goulet et al. 2005). Another possibility is that $R$. rhodostoma and $D$. unguja associ- 
ated with different types of Symbiodinium Clade C, which occurred at low background concentrations not detected in our PCR product. Within Clade C, some subclades (for example, Symbiodinium Type C3) may be more susceptible to bleaching in corals than other Symbiodinium types, such as C15 (La Jeunesse et al. 2003).

Morphological evidence indicates that the ability of some corallimorpharians to survive in HL environments is, at least partly, host-mediated; in that the host endoderm is thicker and zooxanthellae move further away from the mesoglea at high, compared to low, light (Kuguru et al. 2007). In the present study we show that both Rhodactis rhodostoma and Discosoma unguja also protect their algal symbionts biochemically from UV radiation (UVR) through the bioacumulation of UV (295 to $400 \mathrm{~nm}$ ) absorbing compounds (S320, Shibata 1969, Dunlap et al. 1986) in their tissue (Fig. 5). These compounds are most likely mycosporine-like amino acids (MAAs) synthesized by the endosymbiotic algae and then translocated to the host tissues (Banaszak et al. 2000) or they could be obtained through heterotrophic nutrition. The role of MAAs as a protective filter against UV has been found in a variety of marine organisms, including corals, which are known to increase their concentrations of MAAs in response to increased UVR exposure (Shick et al. 1999, Banaszak et al. 2000). Largely transparent to PAR, MAAs efficiently absorb UVR and dissipate UV energy as heat without forming potentially toxic, reactive oxygen species (Shick et al. 1999). Some MAAs and their precursors may also serve as antioxidants by reducing oxygen toxicity within corals and, thus, increasing their ability to survive in habitats with light and temperature perturbations or other stresses that mediate the production of reactive oxygen species (ROS) (Tchernov et al. 2004, Yakovleva \& Hidaka 2004). Our study is consistent with previous studies (Dunlap et al. 1986) that found that UV-absorbing compounds decreased with depth among corals.

The acclimation of the corallimorpharians examined here to changing environmental parameters may depend, in part, on the phenotypic variability of their symbiotic algal assemblages, which are reflected in the cladistic-based phylogeny of Symbiodinium spp. (LaJeunesse 2001, Baker et al. 2004). Phenotypic variation within zooxanthellae clades may even be detected at the genotypic level (Tchernov et al. 2004). Our description of the dynamics of the symbiotic algae within each of these cnidarian hosts is important for understanding their abilities to acclimate to different microhabitats on the coral reef. Some of the ITS2 symbionts we detected in these corallimorpharians (e.g. Clade C) are the most common type associated with cnidarians in the northern Red Sea (Karako-Lampert et al. 2004, Kuguru et al. 2007). In contrast, these 2 corallimorpharian species appear to be the only hexacorallians in this region so far to also associate with Clade D zooxanthellae. In the southern Red Sea and other regions, Symbiodinium from Clade D associate with a variety of cnidarian hosts in marginal habitats where they are exposed to environmental stressors, such as extreme light and temperature (Baker 2003, Rowan 2004, Goulet 2006). Our observation that individuals of both Rhodactis rhodostoma and Discosoma unguja transplanted from deep to shallow areas either shuffled their algae from Type D1a (25\% of polyps) to Type $\mathrm{C} 1$, or remained with Type C1 $(75 \%)$, indicates a different host-algal up-regulation between these depths on the reef. Even though zooxanthellae Clade D is known to be stress-resilient (Baker 2003, Rowan 2004), in this particular case, the selection process at high levels of irradiance in shallow water favored Type C1 rather than the resilient Type D1a. Both highly vulnerable and resilient corals can be inhabited by stress-susceptible symbionts (LaJeunesse et al. 2004); therefore, without a clear competitive advantage, the dominance of 1 algal type over another within a given host may result from complex and dynamic ecophysiological events under internal or external control, such as the cellular mechanisms initiating symbiosis or physical forcing from light, temperature and nutrient availability (Warner et al. 2006). Additionally, while symbionts from different clades are evolutionarily divergent, convergence in physiological adaptations to HL or LL has occurred among symbiont types in different clades (Tchernov et al. 2004). This may occur even within a clade (Sampayo et al. 2007), since the radiation of Symbiodinium spp. occurred almost 32 million yr ago (Tchernov et al. 2004). Thus, while genetically unique, several Symbiodinium types may share ecological niches based on similar distribution and physiology.

The ability of corallimorpharians to occupy different niches within the reef depends on the physiological capacity of the holosymbiont. When exposed to HL stress (Table 4, Fig. 4), individuals of Rhodactis rhodostoma hosting only 1 type of symbiont genotype regulated the efficiency of photosynthesis better than those of Discosoma unguja that hosted multiple algal genotypes. This may suggest that corallimorpharians harboring 1 type of symbiont (e.g. genetically separated based on ITS2 analysis) are more resilient to environmental stresses compared to cnidarians hosting multiple types of symbionts. Support for the latter can be found in infectivity studies that indicate cnidarian hosts favor their homologous algae while discriminating against heterologous symbiont types. Moreover, specimens that accept heterologous symbiont types display reduced fitness and growth (Little et al. 2004, Stat et al. 2006). 
During photoacclimation, each corallimorpharian host species displayed a different pattern of association with zooxanthellae types. During reciprocal transplantation in the field and during light and recovery from induced bleaching in the laboratory, all specimens of Rhodactis rhodostoma contained the same symbiont Type $\mathrm{C} 1$ for over 9 mo, regardless of drastic changes in depth (transplantation from 20 to $5 \mathrm{~m}$ and back to $20 \mathrm{~m}$ ), light exposure, or temperature (Tables 6 \& 7). In contrast, some individuals of Discosoma unguja demonstrated a shift in algal types at both the reciprocal depth and light manipulation experiments. Our observations of symbiont-type consistency in $R$. rhodostoma are similar to those of other studies (Goulet et al. 2005), demonstrating that coral host-symbiont combinations within given geographical areas may withstand major changes in environmental conditions. Most coral species examined exhibit fidelity to a single zooxanthellae clade, some even to specific algal genotypes within a clade (Goulet \& Coffroth 2003, Goulet 2006, Thornhill et al. 2006). Such corals do not tend to change their symbiont types over time, even if the coral is transplanted to different environments or subjected to stressors such as disease or increased temperatures. This pattern is similar to the response of the corallimorpharian $R$. rhodostoma to various environmental conditions. However, the response of $D$. unguja is unique and reveals an unusual alteration of zooxanthellae types with changes in environment.

We conclude that the corallimorpharians Rhodactis rhodostoma and Discosoma unguja show different bathymetric distributional patterns in the northern Red Sea, partly due to photoacclimation mechanisms contributed by both host and algal symbionts to the holobiont. While the hosts bioaccumulate sun-screening, UV-absorbing compounds, the algae photoacclimate physiologically by down-regulating the excitation energies and avoiding chronic photoinhibition (as reflected in maintained high $F_{\mathrm{v}} / F_{\mathrm{m}}$ values). It is also possible that the ability of the host to shuffle different Symbiodinium ITS2 type at various depths contributes to successful photoadaptation by these corallimorpharian hosts to changes in irradiance. The different algal symbionts present in these hosts appeared to be environmental specialists (e.g. Symbiodinuim Type D1a), showing a clear preference for certain depths and environmental parameters, while others appeared to be environmental generalists (e.g. Symbiodinium Type C1) found at all depth ranges. The host species $R$. rhodostoma, which associated with only 1 type of algal symbiont, better tolerated HL and temperature stress than did the host species D. unguja, which associated with multiple symbionts, potentially contributing, in part, to the inverse bathymetric distributional patterns of these 2 hosts. In addition, based on studies by
Edmunds (2007) on ecophysiological response of clonal corallimorpharians Corynactis californica to environmental changes, we can classify $R$. rhodostoma as an environmental generalist and $D$. unguja as an environmental specialist. Finally, the remnant algal symbiont types, which continue to inhabit individuals of $R$. rhodostoma at high temperatures, appear to represent a symbiont pool that could potentially repopulate reef corals following temperature-induced or other stress-related bleaching events in this region.

Acknowledgements. We gratefully acknowledge the technical assistance of the IUI staff and students in various aspects of the field studies. We thank Professor S. Beer for allowing us to use the diving PAM. We appreciate the assistance of S. Victor and B. Goodman during manuscript preparation. This research was supported by funds from Bar-Ilan University, Interuniversity Institute for Marine Science, Auburn University, and Israeli Science Foundation grant \#981/05. This research was submitted in partial fulfillment of the requirements for a doctoral degree by B.K. at Bar-Ilan University. Experiments performed in this study comply with the current laws of Israel.

\section{LITERATURE CITED}

Baker AC (2003) Flexibility and specificity in coral-algal symbiosis: Diversity, ecology, and biogeography of Symbiodinium. Annu Rev Ecol Evol Syst 34:661-689

Baker AC, Starger CJ, McClanahan TR, Glynn PW (2004) Corals' adaptive response to climate change. Nature 430: 741

Banaszak AT, LaJeunesse TC, Trench RK (2000) The synthesis of mycosporine-like amino acids (MAAs) by cultured, symbiotic dinoflagellates. J Exp Mar Biol Ecol 249: 219-233

Barnes D (1973) Growth in colonial scleractinians. Bull Mar Sci 23:280-298

Beer S, Ilan M, Eschel A, Weil A, Brickner I (1998) Use of pulse amplitude modulated (PAM) fluorometry for in situ measurements of photosynthesis in two Red Sea faviid corals. Mar Biol 131:607-612

> Berner RA (1992) Palaeo- $\mathrm{CO}_{2}$ and climate. Nature 358:114

Bradford MM (1976) Rapid and sensitive method for quantitation of microgram quantities of protein utilizing principle of protein-dye binding. Anal Biochem 72:248-254

Buddemeier RW (1996) Coral reefs and carbon dioxide. Science 271:1298-1299

Chadwick-Furman NE (1996) Reef coral diversity and global change. Glob Change Biol 2:559-568

Chadwick-Furman NE, Spiegel M (2000) Abundance and clonal replication in the tropical corallimorpharian Rhodactis rhodostoma. Invertebr Biol 119:351-360

Coffroth MA, Lasker HR, Diamond ME, Bruenn JA, Bermingham E (1992) DNA fingerprints of a gorgonian coral-a method for detecting clonal structure in a vegetative species. Mar Biol 114:317-325

den-Hartog J (1980) Caribbean shallow water Corallimorpharia. Zool Verhand 176:1-82

Dove S, Ortiz JC, Enriquez S, Fine M and others (2006) Response of holosymbiont pigments from the scleractinian coral Montipora monasteriata to short-term heat stress. Limnol Oceanogr 51:1149-1158 
Dunlap WC, Chalker BE, Oliver JK (1986) Bathymetric adaptations of reef-building corals at Davies reef, Great-Barrier-Reef, Australia. 3. UV-B absorbing compounds. J Exp Mar Biol Ecol 104:239-248

- Dunn SR, Bythell JC, Le Tissier MDA, Burnett WJ, Thomason JC (2002) Programmed cell death and cell necrosis activity during hyperthermic stress-induced bleaching of the symbiotic sea anemone Aiptasia sp. J Exp Mar Biol Ecol 272: 29-53

Edmunds PJ (2007) Physiological ecology of the clonal corallimorpharian Corynactis californica. Mar Biol 150:783-796

Falkowski PG, Dubinsky Z (1981) Light-shade adaptation of Stylophora pistillata, a hermatypic coral from the Gulf of Eilat. Nature 289:172-174

Fine M, Tchernov D (2007) Scleractinian coral species survive and recover from decalcification. Science 315:1811

Franklin LA, Seaton GR, Lovelock CE, Larkum AWD (1996) Photoinhibition of photosynthesis on a coral reef. Plant Cell Environ 19:825-836

Gates RD, Edmunds PJ (1999) The physiological mechanisms of acclimatization in tropical reef corals. Am Zool 39:30-43

Genty B, Briantais J, Baker N (1989) The relationship between quantum yield of photosynthetic electron transport and quenching of chlorophyll fluorescence. Biochim Biophys Acta 990:87-92

Goulet TL (2006) Most corals may not change their symbionts. Mar Ecol Prog Ser 321:1-7

Goulet TL, Coffroth MA (2003) Stability of an octocoral-algal symbiosis over time and space. Mar Ecol Prog Ser 250: $117-124$

Goulet TL, Cook CB, Goulet D (2005) Effect of short-term exposure to elevated temperatures and light levels on photosynthesis of different host-symbiont combinations in the Aiptasia pallidal Symbiodinium symbiosis. Limnol Oceanogr 50:1490-1498

Hall TA (1999) BioEdit: a user-friendly biological sequence alignment editor and analysis program for Windows 95/98/NT. Nucleic Acids Symp Ser 41:95-98

- Hirose E, Hirabayashi S, Hori K, Kasai F, Watanabe MM (2006) UV protection in the photosymbiotic ascidian Didemnum molle inhabiting different depths. Zoolog Sci 23:57-63

Hoegh-Guldberg O (1999) Climate change, coral bleaching and the future of the world's coral reefs. Mar Freshw Res 50:839-866

- Hoegh-Guldberg O, Jones RJ (1999) Photoinhibition and photoprotection in symbiotic dinoflagellates from reefbuilding corals. Mar Ecol Prog Ser 183:73-86

Iglesias-Prieto R, Trench RK (1997) Acclimation and adaptation to irradiance in symbiotic dinoflagellates. II. Response of chlorophyll-protein complexes to different photon-flux densities. Mar Biol 130:23-33

Iglesias-Prieto R, Beltran VH, LaJeunesse TC, Reyes-Bonilla $H$, Thome PE (2004) Different algal symbionts explain the vertical distribution of dominant reef corals in the eastern Pacific. Proc R Soc Lond B Biol Sci 271:1757-1763

Jeffrey SW, Humphrey GF (1975) New spectrophotometric equations for determining chlorophylls $\mathrm{a}, \mathrm{b}, \mathrm{c}_{1}$ and $\mathrm{c}_{2}$ in higher-plants, algae and natural phytoplankton. Biochem Physiol Pflanz 167:191-194

Karako-Lampert S, Katcoff DJ, Achituv Y, Dubinsky Z, Stambler N (2004) Do clades of symbiotic dinoflagellates in scleractinan corals of the Gulf of Eilat (Red Sea) differ from those of other coral reefs? J Exp Mar Biol Ecol 311: 301-314

Kinzie RA (1993) Effects of ambient levels of solar ultraviolet radiation on zooxanthellae and photosynthesis of the reef coral Montipora verrucosa. Mar Biol 116:319-327

Kinzie RA, Hunter T (1987) Effect of light quality on photosynthesis of the reef coral Montipora verrucosa. Mar Biol 94: 95-109

Kuguru BL, Mgaya YD, Ohman MC, Wagner GM (2004) The reef environment and competitive success in the Corallimorpharia. Mar Biol 145:875-884

Kuguru B, Winters G, Beer S, Santos S, Chadwick N (2007) Adaptation strategies of the corallimorpharian Rhodactis rhodostoma to irradiance and temperature. Mar Biol 151: $1287-1298$

LaJeunesse TC (2001) Investigating the biodiversity, ecology, and phylogeny of endosymbiotic dinoflagellates in the genus Symbiodinium using the ITS region: In search of a 'species' level marker. J Phycol 37:866-880

$>$ LaJeunesse TC (2002) Diversity and community structure of symbiotic dinoflagellates from Caribbean coral reefs. Mar Biol 141:387-400

LaJeunesse TC, Loh WK, Woesik RV, Hoegh-Guldberg O, Schmidt GW, Fitt WK (2003) Low symbiont diversity in Southern Great Barrier Reef corals relative to those of the Carribbean. Limnol Oceanogr 48:2046-2054

> LaJeunesse TC, Bhagooli R, Hidaka M, DeVantier L and others (2004) Closely related Symbiodinium spp. differ in relative dominance in coral reef host communities across environmental, latitudinal and biogeographic gradients. Mar Ecol Prog Ser 284:147-161

Levy O, Achituv Y, Yacobi YZ, Stambler N, Dubinsky Z (2006) The impact of spectral composition and light periodicity on the activity of two antioxidant enzymes (SOD and CAT) in the coral Favia favus. J Exp Mar Biol Ecol 328:35-46

Little AF, van Oppen MJH, Willis BL (2004) Flexibility in algal endosymbioses shapes growth in reef corals. Science 304 : $1492-1494$

Loya Y (1985) Seasonal changes in growth rate of a Red Sea coral population. Proc 5th Intl Coral Reef Congress, Tahiti 6:187-191

- Mass T, Einbinder S, Brokovich E, Shashar N, Vago R, Erez J, Dubinsky Z (2007) Photoacclimation of Stylophora pistillata to light extremes: metabolism and calcification. Mar Ecol Prog Ser 334:93-102

Maxwell DP, Falk S, Huner NPA (1995) Photosystem-II excitation pressure and development of resistance to photoinhibition. 1. Light-harvesting complex-II abundance and zeaxanthin content in Chlorella vulgaris. Plant Physiol 107:687-694

Medina M, Collins AG, Takaoka TL, Kuehl JV, Boore JL (2006) Naked corals: skeleton loss in Scleractinia. Proc Natl Acad Sci USA 103:9096-9100

Muscatine L, McCloskey LR, Marian RE (1981) Estimating the daily contribution of carbon from zooxanthellae to coral animal respiration. Limnol Oceanogr 26:601-611

Nir O (2006) Changes in the coral Seriatopora hystrix along a depth gradient from its shallow to its deep distributional range, in the Gulf of Eilat. MSc thesis, Hebrew University of Jerusalem (in Hebrew with English abstract)

> Rowan R (2004) Coral bleaching: thermal adaptation in reef coral symbionts. Nature 430:742

Sampayo EM, Franceschinis L, Hoegh-Guldberg OVE, Dove S (2007) Niche partitioning of closely related symbiotic dinoflagellates. Mol Ecol 16:3721-3733

Scheiner S, Gurevitch J (2001) Design and analysis of ecological experiments. Oxford University Press, New York

Shibata K (1969) Pigments and a UV-absorbing substance in coral and bluegreen algae living in the Great Barrier Reef. Pl Cell Physiol Tokyo 10:325-335

Shick JM, Romaine-Lioud S, Ferrier-Pages C, Gattuso JP 
(1999) Inhibition of the shikimate pathway blocks UVB radiation-stimulated accumulation of mycosporine-like amino acids (MAAs) in the coral Stylophora pistillata. Photochem Photobiol 69:93S

Stambler N, Dubinsky Z (2004) Stress effects on metabolism of the hermatypic coral. In: Rosenberg E, Loya Y (eds) Coral health and disease. Springer-Verlag, Berlin, p 195-215

Stanley GD (2003) The evolution of modern corals and their early history. Earth Sci Rev 60:195-225

Stat M, Carter D, Hoegh-Guldberg O (2006) The evolutionary history of Symbiodinium and scleractinian hosts-symbiosis, diversity, and the effect of climate change. Perspect Plant Ecol Evol Syst 8:23-43

Tchernov D, Gorbunov MY, de Vargas C, Yadav SN, Milligan AJ, Haggblom M, Falkowski PG (2004) Membrane lipids of symbiotic algae are diagnostic of sensitivity to thermal bleaching in corals. Proc Natl Acad Sci USA 101: 13531-13535

Editorial responsibility: Peter Edmunds, Northridge, California, USA
Thornhill DJ, LaJeunesse TC, Kemp DW, Fitt WK, Schmidt GW (2006) Multi-year, seasonal genotypic surveys of coral-algal symbioses reveal prevalent stability or postbleaching reversion. Mar Biol 148:711-722

van Oppen MJH, Gates RD (2006) Conservation genetics and the resilience of reef-building corals. Mol Ecol 15: 3863-3883

Warner ME, LaJeunesse TC, Robison JD, Thur RM (2006) The ecological distribution and comparative photobiology of symbiotic dinoflagellates from reef corals in Belize: potential implications for coral bleaching. Limnol Oceanogr 51: 1887-1897

Winters G, Loya Y, Rottgers R, Beer S (2003) Photoinhibition in shallow-water colonies of the coral Stylophora pistillata as measured in situ. Limnol Oceanogr 48:1388-1393

Yakovleva I, Hidaka M (2004) Diel fluctuations of mycosporine-like amino acids in shallow-water scleractinian corals. Mar Biol 145:863-873

Submitted: March 31, 2008; Accepted: July 14, 2008

Proofs received from author(s): September 21, 2008 